\title{
Pengaruh Promosi Terhadap Peningkatan Volume Penjualan UMKM Keripik Pisang Di Gang PU Bandar Lampung
}

\author{
Tiar Mirnasari $^{(1)}$, Yuliana Yamin ${ }^{1)}$ \\ Universitas Islam Sultan Agung \\ tiarmirnasari2021@gmail.com
}

\begin{abstract}
Abstrak.
Permasalahan dalam penelitian ini adalah apakah ada pengaruh promosi terhadap peningkatan volume penjualan keripik pisang di Gang PU Bandar Lampung? Tujuan penelitian ini adalah untuk mengetahui pengaruh promosi terhadap peningkatan volume penjualan. Hipotesis yang penulis ajukan adalah ada pengaruh promosi terhadap peningkatan volume penjualan. Penelitian ini menggunakan metode penelitian deskriptif dengan analisis kualitatif dan analisis kuantitatif. Pengumpulan data penelitian menggunakan teknik purposive sampling yang menjadi sampel sebanyak 25 responden. Berdasarkan hasil analisis, ditemukan pengaruh promosi terhadap penjualan dengan peningkatan volume penjualan pengaruh ( $R$-Square) sebesar $24,6 \%$ yang berarti promosi memberikan pengaruh sebesar $24,6 \%$ terhadap peningkatan volume penjualan. Hasil prsamaan regresi antara promosi dan peningkatan volume penjualan UMKM Kripik Pisang di Gang PU Bandar lampung menunjukkan setiap kenaikan satu point dari variable promosi akan diikuti oleh naiknya variabel peningkatan volume penjualan sebesar 0,769 point.
\end{abstract}

Kata kunci: Pengaruh Promosi, Peningkatan, Penjualan, UMKM

\begin{abstract}
.
The problem in this study is whether there is a promotion effect on increasing sales volume of banana chips in Gang PU Bandar Lampung? The purpose of this study was to determine the effect of promotion on increasing sales volume. The hypothesis that the author proposes is that there is a promotion effect on increasing sales volume. This study uses descriptive research methods with qualitative analysis and quantitative analysis. Collecting research data using purposive sampling technique which became a sample of 25 respondents. Based on the results of the analysis, it was found the effect of promotion on sales with an increase in sales volume of influence (R-Square) of $24.6 \%$, which means that promotion has an effect of $24.6 \%$ on increasing sales volume. The regression equation between the promotion and the increase in sales volume of UMKM Kripik Pisang in Gang PU Bandar Lampung shows that every one point increase in the promotion variable will be followed by an increase in the sales volume variable by 0.769 points.
\end{abstract}

Keywords: Effect of promotion, Increasing, Saling, UMKM

\section{PENDAHULUAN}

Provinsi Lampung yang dikenal sebagai salah satu provinsi penghasil pisang terbesar di Indonesia, tidak heran bila pisang menjadi salah makanan favorit dan menjadi peluang bisnis sebagai buah tangan khas provinsi Lampung salah satunya yaitu kripik pisang. Pertumbuhan bidang usaha penjualan keripik merupakan salah satu bidang usaha yang pertumbuhannya sangat pesat di wilayah Bandar Lampung. Permintaan akan kebutuhan keripik sebagai makanan camilan ringan khas lampung yang juga dapat dijadikan buah tangan semakin tahun terus meningkat seiring dengan pertumbuhan penduduk dan meningkatnya tingkat pendapatan masyarakat. Hal ini tentu sangat berpengaruh terhadap maraknya jenis varian rasa dan bentuk dari berbagai macam merek yang beredar dipasaran dapat menimbulkan masalah, dimana terjadi persaingan yang sengit dalam hal menarik konsumen yang dapat mempengaruhi tingkat penjualan.

Untuk menarik minat konsumen membeli dengan melakukan kegiatan promosi yang tepat sebagai alat untuk meningkatkan volume penjualan sehingga konsumen diharapkan menjadi loyal 
terhadap perusahaan. Sejalan dengan hal tersebut, upaya yang dapat dilakukan dalam memasarkan suatu produk yakni dengan melakukan kegiatan promosi yang meliputi, advertising, sales promotion, personal selling, public relation, direct marketing agar calon konsumen lebih mengenal, memahami, serta simpati terhadap produk yang ditawarkan (Nugraheni, Prihatini and Budiatmo, 2014).
Demikian halnya dengan indutri UMKM Kripik Pisang di Gang PU Bandar Lampung tentu sangat memperhatikan sistem pemasaran dengan alat promosi untuk meningkatkan penjualan keripik pisang. Berikut ini merupakan tabel penjualan UMKM Kripik Pisang di Gang PU periode tahun 2016 - 2020.

Tabel 1. Volume Penjualan Keripik Pisang di Gang PU Bandar Lampung

\begin{tabular}{ccc}
\hline Tahun & Volume Penjualan & Perkembangan Penjualan (\%) \\
\hline 2016 & 991 & - \\
2017 & 1.098 & 9,74 \\
2018 & 1.231 & 10,80 \\
2019 & 1.578 & 21,98 \\
2020 & 1.479 & $-6,69$ \\
\hline
\end{tabular}

Dari 25 orang responden, promosi (X) pada UMKM Kripik Pisang di Gang PU Bandar Lampung yang mengatakan dalam kategori "sangat baik" ada 9 orang (36\%), yang menyatakan "baik" ada 14 orang $(56 \%)$ , dan yang menyatakan "sedang" ada.

\section{METODE PENELITIAN}

Penelitian ini dilakukan dibagian penjualan pada UMKM Keripik Pisang di Gang PU Bandar Lampung yang beralamat di Jl. Pagar Alam Segala Mider Tanjung Karang Barat Bandar Lampung.

Dalam penelitian ini metode pengumpulan data yang dipergunakan dalam penelitian ini ada dua, yaitu data primer yaitu data yang diperoleh dari keterangan langsung dari responden atau objek penelitian yang ada hubungannya dengan judul penelitian yang dapat diperoleh secara langsung melalui hasil pengamatan maupun wawancara yang berkaitan dengan masalah penelitian pada UMKM Kripik Pisang di Gang PU Bandar Lampung.

Untuk memperoleh data penelitian ini dilakukan dengan empat teknik pengumpulan data yaitu observasi, wawancara, dokumentasi dan kuesioner kepada responden.

Populasi menurut Sugiyono (2015) adalah, "Wilayah generalisasi yang terdiri atas: obyek/subyek yang mempunyai kualitas dan karakteristik tertentu yang ditetapkan oleh peneliti untuk dipelajari dan kemudian ditarik kesimpulannya. "Berdasarkan pengertian tersebut, maka yang menjadi populasi dalam penelitian ini adalah karyawan pada UMKM Keripik Pisang di Gang PU Bandar Lampung sebanyak 25 responden.

Teknik sampel adalah cara untuk menentukan sampel yang dapat mewakili populasi. Menurut Sugiyono (2015) "Sampel adalah bagian dari jumlah dan karakteristik yang dimiliki oleh populasi." Peneliti menerapkan teknik sampel yang mengambil $100 \%$ dari populasi sebagai sampel dikarenakan jumlah populasi yang kurang dari 100 responden. Sedangkan purposive sampling menurut Sugiyono (2015), adalah "Teknik pengambilan sampel sumber data dengan pertimbangan tertentu." Dalam penelitian ini yang menjadi sampel 
adalah karyawan pada UMKM Kripik Pisang di Gang PU Bandar Lampung sebanyak 25 responden.

Dalam penelitian ini digunakan metode analisis kuantitatif yaitu suatu analisis dilakukan dengan statistic menggunakan rumus regresi linier sederhana.

Data yang diperoleh nantinya akan diolah menggunakan program olah data komputer yaitu SPSS versi 20 untuk menghasilkan nilai koefisien determinasi yang lebih akurat.

\section{HASIL DAN PEMBAHASAN}

Analisis kualitatif digunakan dengan menjelaskan atau mendeskripsikan hasil perhitungan yang dilakukan dengan berdasar teori atau konsep yang digunakan. Berikut data distribusi hasil tanggapan responden variabel promosi $(\mathrm{X})$ dan Peningkatan volume penjualan $(\mathrm{Y})$ secara keseluruhan

Tabel 2. Distribusi Data Promosi (X) secara keseluruhan

\begin{tabular}{ccccc}
\hline No & Skor & Kategori & Frekuensi & $\%$ \\
\hline 1 & $41-50$ & Sangat Baik & 9 & $36 \%$ \\
2 & $31-40$ & Baik & 14 & $56 \%$ \\
3 & $21-30$ & Sedang & 2 & $8 \%$ \\
4 & $11-20$ & Buruk & - & - \\
5 & $0-10$ & Sangat Buruk & - & - \\
& & Jumlah & 25 & $100 \%$ \\
\hline
\end{tabular}

(8\%). Sedangkan yang menyatakan "buruk"

Dari 25 orang responden, promosi (X) dan "sangat buruk" tidak ada (0\%). promosi pada UMKM Kripik Pisang di Gang PU (X) dan Peningkatan volume penjualan (Y) Bandar Lampung yang mengatakan dalam secara keseluruhan.

kategori "sangat baik" ada 9 orang (36\%), yang menyatakan "baik" ada 14 orang $(56 \%)$ , dan yang menyatakan "sedang" ada 2 orang

Tabel 3. Distribusi Data Volume Penjualan (Y) secara keseluruhan

\begin{tabular}{ccccc}
\hline no & Skor & Kategori & Frekuensi & $\%$ \\
\hline 1 & $41-50$ & Sangat Baik & 7 & $28 \%$ \\
2 & $31-40$ & Baik & 15 & $60 \%$ \\
3 & $21-30$ & Sedang & 3 & $12 \%$ \\
4 & $11-20$ & Buruk & - & - \\
5 & $0-10$ & Sangat Buruk & - & - \\
& & Jumlah & 25 & $100 \%$ \\
\hline
\end{tabular}

Dari 25 orang responden, promosi $(\mathrm{X})$ pada UMKM Kripik Pisang di Gang PU Bandar Lampung yang mengatakan dalam kategori "sangat baik" ada 7 orang $(28 \%)$, yang menyatakan "baik" ada 15 orang $(60 \%)$ , dan yang menyatakan "sedang" ada 3 orang $(12 \%)$. Sedangkan yang menyatakan "buruk" dan "sangat buruk" tidak ada (0\%).
Analisis kuantitatif digunakan untuk mengetahui pengaruh antara kedua variabel yang diteliti. Nilai koefisien determinasi (r) ada dua arah, nilai positif yaitu menunjukkan hubungan yang searah (X naik maka Y naik) dan nilai positif menunjukkan hubungan terbalik (X naik maka Y turun).

Koefisien Determinasi promosi (X) terhadap peningkatan volume penjualan (Y) yaitu $0,246 \times 100 \%=24,6 \%$. Hal ini 
menunjukkan bahwa variabel promosi (X) menjelaskan perubahan terhadap variabel peningkatan volume penjualan $(\mathrm{Y})$ sebesar $24,6 \%$ sedangkan sisanya dijelaskan oleh faktor lain yang tidak dikaji dalam penelitian ini. Standard Error of Estimate adalah suatu ukuran banyaknya kesalahan model regresi dalam memprediksikan nilai X. Dari hasil regresi didapat nilai 4,312 Sementara besarnya pengaruh yang diberikan variabel (X) terhadap variabel Y (R Square) adalah sebesar 0,246 atau $24,6 \%$.

Tabel 4. Uji Hipotesis

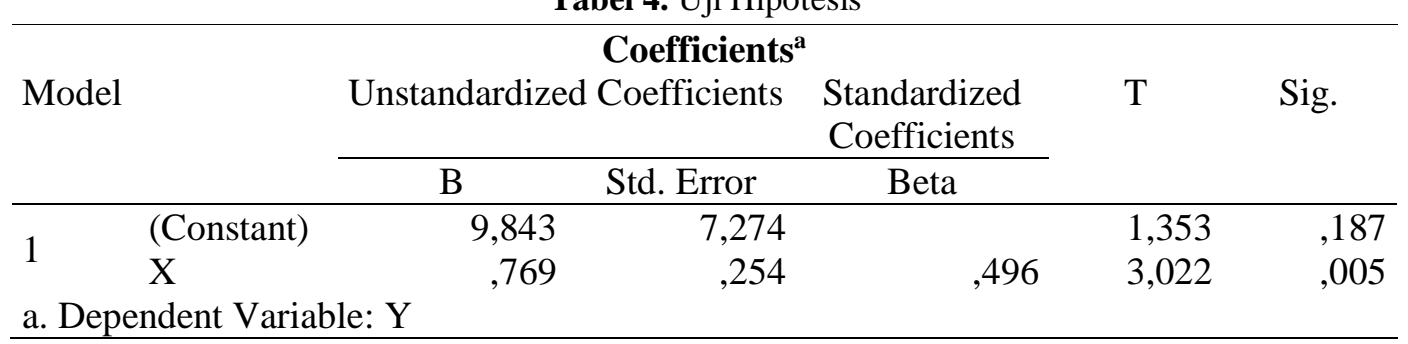

a. Dependent Variable: Y

Berdasarkan hasil uji $t$ dapat disimpulkan bahwa variabel promosi (X) berpengaruh terhadap peningkatan volume penjualan (Y). Berdasarkan kondisi tersebut, bentuk persamaan regresinya sebagai berikut:

$$
\mathrm{Y}=9,843+0,769 \mathrm{X}+\mathrm{e}
$$

Dimana :

$$
\begin{array}{ll}
\mathrm{Y} & =\text { Peningkatan volume penjualan } \\
\mathrm{a} & =\text { konstanta } \\
\mathrm{b} & =\text { Koefisien Regresi } \mathrm{X} \\
\mathrm{X} & =\text { Promosi } \\
\mathrm{e} & =\text { error term (tingkat kesalahan) }
\end{array}
$$

Dari persamaan regresi diatas dapat dijelaskan bahwa dengan nilai koefisien promosi yang positif menunjukkan apabila promosi meningkat baik maka volume penjualan akan meningkat. Nilai koefisien promosi sebesar 0,769 menunjukkan apabila promosi meningkat sebesar 1 satuan maka volume penjualan juga akan meningkat sebesar 0,769 satuan.

Hasil penelitian menunjukkan bahwa promosi (X) pada UMKM Keripik Pisang di Gang PU Bandar Lampung dalam kategori cukup baik, tingkat pengaruh antara variabel melalui program SPSS version 20 diperoleh besarnya tingkat pengaruh antara variabel promosi (X) dengan variabel Volume penjualan (Y) pada UMKM Keripik Pisang di Gang PU Bandar Lampung adalah sebesar 0,496, yaitu dalam kategori sedang. Untuk perhitungan pengaruh variabel promosi pada tabel diatas diperoleh angka $\mathrm{R}^{2}$ (R Square) sebesar 0,246 atau $24,6 \%$.

Hal ini menunjukkan bahwa persentase sumbangan pengaruh variabel independen promosi (X) terhadap variabel dependen volume penjualan (Y) sebesar 24,6\% dan sisanya dipengaruhi faktor lain. Uji hipotesis parsial melalui uji $t$ test diperoleh nilai $t$ hitung antara promosi terhadap volume penjualan sebesar 3,022 $\mathrm{t}_{\text {hitung }}=3,022>\mathrm{t}_{\text {tabel }}=1,714$. Persamaan regresi promosi (X) dengan variabel volume penjualan (Y)adalah sebesarY $=9,843+0,769 \mathrm{X}+\mathrm{e}$, yang menunjukkan setiap kenaikan satu point dari variabel promosi akan diikuti oleh naiknya variabel volume penjualan (Y) sebesar 0,769 point.

\section{KESIMPULAN}

Berdasarkan perhitungan dengan persamaan regresi linier sederhana pengaruh promosi terhadap peningkatan volume penjualan ialah $\mathrm{Y}=9,843+0,769 \mathrm{X}+\mathrm{e}$ yang berarti apabila perusahaan tidak melakukan promosi maka volume penjualan sebesar 9,843, sedangkan apabila melakukan promosi maka koefisien promosi sebesar 
0,769 menunjukkan apabila promosi meningkat sebesar 1 satuan maka volume penjualan juga akan meningkat sebesar 0,769 point atau $76,9 \%$.

\section{DAFTAR PUSTAKA}

Adi Kwartono, 2007, Analisis Usaha Kecil dan Menengah, Yogyakarta : Andi Offset.

Anggarani, 2014, Penguatan Sektor UMKM Sebagai Strategi Menghadapi MEA 2015, Jurnal Ekonomi 5 No.1,42-48

Anggia, M. N., \& Shihab, M. R. (2018). Strategi Media Sosial Untuk Pengembangan Umkm. Jurnal Terapan Teknologi Informasi, 2(2), 159-170.

Nugraheni, R., Prihatini, A. E. and Budiatmo, A. (2014) 'Pengaruh Standar Operasional Prosedur Dan Pengawasan Terhadap Kinerja Pramuniaga Pasaraya Sriratu Pemuda Semarang', Jurnal Ilmu Administrasi Bisnis, 3(2), pp. 187-195. Available at:

https://ejournal3.undip.ac.id/index.ph $\mathrm{p} / \mathrm{jiab} / \mathrm{article} / \mathrm{view} / 5194$.

Sugiyono. 2015,Metode PenelitianKuantitatif Kualitatif dan $R \& D ; \quad$ Penerbit CV Alfabeta, Bandung.

Soekidjo Notoatmodjo. (2005). Metodologi penelitian kesehatan. Jakarta: Rineka Cipta. 